\title{
FAKTOR-FAKTOR YANG MEMPENGARUHI SURPLUS UNDERWRITING DANA TABARRU' PADA PERUSAHAAN ASURANSI JIWA SYARIAH ${ }^{1}$
}

\author{
Rosyda Alifianingrum \\ Mahasiswa Program Studi S1 Ekonomi Islam-Fakultas Ekonomi dan Bisnis-Universitas Airlangga \\ Email: rosyda.alifianingrum-13@feb.unair.ac.id
}

Noven Suprayogi

Departemen Ekonomi Syariah-Fakultas Ekonomi dan Bisnis-Universitas Airlangga

Email: noven.suprayogi@feb.unair.ac.id

\begin{abstract}
ABTRACT:
This study aims to determine factors that affect surplus underwriting of tabarru' fund on Sharia Life Insurance in Indonesia. The factors used in this study is net contribution, claim expenses and investment return. This study used is panel data regression with Econometric Views (EViews) 8.0 as statistical analysis software. The samples are 14 Sharia Life Insurance, consists of 13 Islamic business units and 1 full sharia. During 2011 to 2015, the hypothesis test result showed the factors affecting surplus underwriting of tabarru' fund is net contribution, claim expenses and investment return always showed significant effect partially or simultaneously to the surplus underwriting of tabarru' fund on sharia life insurance.
\end{abstract}

Keywords: Surplus Underwriting, Sharia Life Insurance, Tabarru' Fund, Panel Data Regression

\section{PENDAHULUAN}

\section{Latar Belakang}

Keberadaan industri asuransi di Indonesia sudah ada sejak tahun 1853 dibawa oleh penjajah kolonial Belanda. Asuransi dibutuhkan karena hidup manusia bisa kapan saja terancam resiko, maka dari itu industri asuransi adalah salah satu perusahaan non-bank yang mampu memberikan jaminan perlindungan kepada manusia saat tertimpa musibah atau kerugian. Perusahaan asuransi yang pertama kali berdiri adalah perusahaan asuransi konvensional, dimana di dalamnya terdapat transaksi yang dilarang Islam yaitu adanya maysir, gharar, dan riba. Dengan adanya hal tersebut, maka pada 24 Februari 1994 didirikanlah asuransi syariah pertama di Indonesia yaitu PT. Syarikat Takaful Indonesia (STI) yang mempelopori berdirinya perusahaan asuransi syariah lainnya, baik asuransi unit usaha syariah maupun asuransi full syariah (Dewi, 2005:140)

Asuransi syariah di Indonesia dibagi menjadi tiga jenis yaitu Asuransi Jiwa Syariah, Asuransi Umum Syariah, dan Reasuransi Syariah. Asuransi Jiwa Syariah dan Asuransi Umum Syariah memiliki bentuk unit usaha syariah dan penuh secara syariah (full syariah). Jumlah perusahaan antara Asuransi Umum Syariah dan Asuransi Jiwa Syariah bersaing secara kompetitif, keduanya mampu memahami potensi pasar sehingga tumbuh dan berkembang dengan baik dalam hal kelembagaan (OJK: 2016).

Asuransi syariah berdasarkan Fatwa Dewan Syariah Nasional No. 21/DSN-MUI/X/2001 tentang Pedoman Umum Asuransi Syariah, yaitu usaha saling melindungi dan tolong-menolong di antara sejumlah orang/pihak melalui

1Jurnal ini merupakan bagian dari skripsi yang ditulis oleh Rosyda Alifianingrum, NIM : 041311433052,

yang diuji pada 16 Februari 2017 
Alifianingrum, et al/ Jurnal Ekonomi Syariah Teori dan Terapan Vol. 5 No. 2 Februari 2018: 144158; FAKTOR-FAKTOR YANG MEMPENGARUHI SURPLUS UNDERWRITING DANA TABARRU' PADA PERUSAHAAN ASURANSI JIWA SYARIAH

investasi dalam bentuk aset dan atau tabarru' yang memberikan pola mampu bersaing (Darmawi, 2004: 31-32). pengembalian untuk menghadapi resiko tertentu melalui akad (perikatan) yang sesuai dengan syariah (DSN-MUI:2001). Asas tolong menolong dalam asuransi syariah yang dijadikan sebagai salah satu dasar dalam praktiknya, terdapat dalam firman Allah yang memerintahkan umatnya untuk saling tolong menolong dalam surat Al Maidah (5) ayat 2:

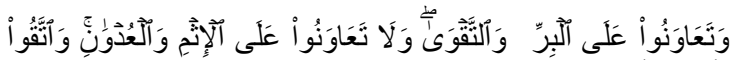

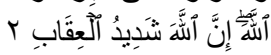

Wata'āwanū 'alal birri wat taqwā wa lā ta'āwanū 'alā al-itsmi wal'udwāni wattaqullāh, innallāha syadīdul'iqāb.

Artinya: "Dan tolong-menolonglah kamu dalam (mengerjakan) kebajikan dan takwa, dan jangan tolong-menolong dalam berbuat dosa dan pelanggaran, dan bertakwalah kamu kepada Allah. Sesungguhnya Allah amat berat siksaNya."

Dana tabarru' yaitu pemberian sukarela dari seseorang kepada orang lain tanpa ganti rugi sehingga berpindahnya kepemilikan harta dari pemberi ke yang diberi dan diberikan secara ikhlas dengan menghadap ridho Allah kepada sesama peserta asuransi yang mendapat musibah (Sula, 2004:35-36).

Dalam pengelolaan dana tabarru' diperlukan proses underwriting. Underwriting yaitu proses penyeleksian dan pengelompokkan resiko yang akan ditanggung oleh peserta. Underwriting sendiri mempunyai maksud memaksimalkan laba yang didapat melalui penerimaan distribusi resiko yang diperkirakan akan mendatangkan laba, tanpa underwriting yang efisien, perusahaan asuransi syariah tidak akan merupakan salah satu hal penting yang harus diperhatikan oleh perusahaan asuransi syariah, karena underwriting merupakan salah satu tolak ukur yang bisa menunjukkan bagaimana perusahaan asuransi syariah tersebut dalam mengelola dana peserta. Hasil underwriting yang tinggi pada perusahaan asuransi, secara umum menunjukkan baiknya proses underwriting yang telah dilakukan, sedangkan penurunan hasil underwriting menunjukkan semakin memburuknya kinerja underwriting selama periode tertentu (Fikri:2009).

Suatu perusahaan asuransi syariah yang mengalami surplus underwriting maka bisa dipastikan bahwa perusahaan tersebut berhasil mengelola dana peserta dengan baik dan dengan adanya surplus underwriting maka akan menumbuhkan kepercayaan masyarakat bahwa perusahaan asuransi tersebut termasuk perusahaan yang baik. Surplus underwriting dana tabarru' juga dapat digunakan sebagai cadangan bagi pembayaran klaim peserta asuransi di masa depan, sehingga resiko gagal bayar terhadap klaim dapat diminimalisir (Karwati:2011).

Sebaliknya, apabila suatu perusahaan asuransi syariah mengalami defisit underwriting maka menujukkan bahwa semakin memburuknya kinerja underwriting dalam perusahaan tersebut, bisa diartikan juga bahwa perusahaan gagal dalam mengelola dana peserta 
Alifianingrum, et al/ Jurnal Ekonomi Syariah Teori dan Terapan Vol. 5 No. 2 Februari 2018: 144158; FAKTOR-FAKTOR YANG MEMPENGARUHI SURPLUS UNDERWRITING DANA TABARRU' PADA PERUSAHAAN ASURANSI JIWA SYARIAH

dengan baik. Dengan adanya defisit underwriting maka akan membuat kepercayaan masyarakat terhadap asuransi tersebut menurun, dan apabila suatu perusahaan asuransi terus-menerus mengalami defisit underwritring maka bisa dipastikan bahwa perusahaan tersebut nantinya bisa tutup dan tidak layak untuk menjalankan operasionalnya lagi (Karwati:2011).

Surplus/defisit underwriting dana tabarru' berdasarkan laporan keuangan pada asuransi syariah berhubungan langsung dengan beberapa faktor, yaitu kontribusi, beban klaim, dan hasil investasi pengelolaan dana tabarru' peserta (Damayanti:2016).

Kontribusi yaitu sejumlah dana yang dibayarkan peserta kepada perusahaan asuransi dengan maksud apabila suatu saat mendapatkan musibah/kerugian bisa digunakan untuk mengajukan klaim. Kontribusi pada asuransi syariah terdiri dari dana tabungan dan dana tabarru' sesuai dengan kesepakatan dalam akad. Kontribusi awal yang dibayarkan peserta disebut dengan kontribusi bruto, kontribusi bruto ini akan dikurangi oleh beberapa biaya sebelum menjadi kontribusi bersih atau kontribusi neto. Kontribusi yang langsung mempengaruhi surplus/defisit underwriting adalah kontribusi neto, yaitu dana tabarru' dikurangi dengan biaya reasuransi (Sula, 2004:249).

Beban klaim atau beban asuransi merupakan salah satu faktor yang juga mempengaruhi surplus/defisit underwriting dana tabarru' karena berhubungan langsung. Menurut fatwa Dewan Syariah Nasional Majelis Ulama Indonesia No.21/DSN-MUI/X/2001 tentang pedoman umum asuransi syariah, klaim adalah hak peserta yang merupakan kewajiban perusahaan asuransi untuk memenuhinya, klaim dibayarkan berdasarkan akad yang disepakati pada awal perjanjian. Apabila terjadi klaim maka perusahaan asuransi syariah akan mengganti kerugian peserta tersebut dengan menggunakan dana tabarru' atau dana kebajikan yang telah dikumpulkan oleh para peserta asuransi (Sula, 2004:315).

Menurut fatwa Dewan Syariah Nasional No.53/DSN-MUI/III/2006 tentang Akad Tabarru' pada Perusahaan Asuransi Syariah, investasi diperlukan untuk mengelola dana tabarru' peserta agar apabila tidak ada klaim dana tersebut tidak menganggur begitu saja, namun dapat digunakan untuk berinvestasi dan mendapatkan keuntungan di masa yang akan datang dan hasil investasinya bisa dibagi antara peserta dan perusahaan sesuai dengan yang disepakati pada akad (DSN-MUI:2006).

Kontribusi neto, beban klaim dan hasil investasi secara teoritis mempunyai hubungan dengan surplus/defisit underwriting dana tabarru'. Kontribusi neto yang merupakan bagian dari kontribusi bruto, apabila kontribusi/premi perusahaan asuransi meningkat maka kontribusi netonya pun akan meningkat (Sula, 2004:311). 
Alifianingrum, et al/ Jurnal Ekonomi Syariah Teori dan Terapan Vol. 5 No. 2 Februari 2018: 144158; FAKTOR-FAKTOR YANG MEMPENGARUHI SURPLUS UNDERWRITING DANA TABARRU' PADA PERUSAHAAN ASURANSI JIWA SYARIAH

Sedangkan, klaim pada asuransi syariah bersifat mengurangi dana tabarru' peserta sehingga hal ini akan berdampak pada surplus underwriting dana tabarru', jadi apabila klaim naik, maka surplus underwriting akan menurun (Nurcahya:2012).

Hasil investasi berhubungan lurus dengan surplus underwriting karena investasi adalah penanaman modal/aset yang akan mendapatkan keuntungan di masa yang akan datang, jadi apabila investasi yang dilakukan oleh perusahaan asuransi syariah terhadap dana tabarru meningkat maka hal ini bisa menyebabkan kenaikan pada surplus (defisit) underwriting dana tabarru' (Nurcahya:2012).

Tabel 1.2

Jumlah Kontribusi, Beban Klaim, Hasil Investasi, dan Surplus (Defisit) Underwriting Dana Tabarru' Asuransi Umum dan Reasuransi Syariah (dalam jutaan rupiah)

\begin{tabular}{|c|c|c|c|c|}
\hline Tahun & Kontribusi & Klaim & Investasi & $\begin{array}{c}\text { Surplus } \\
\text { (Defisit) } \\
\text { Underwriting }\end{array}$ \\
\hline 2012 & $504.436,5$ & $379.486,6$ & 38.811 & 107.962 \\
\hline 2013 & 932.945 & 803.168 & 69.987 & 50.316 \\
\hline 2014 & 1.280 .972 & 814.430 & 71.938 & 142.627 \\
\hline
\end{tabular}

Sumber:www.ojk.go.id, diolah kembali.

Dalam tabel diatas, ditunjukkan

bahwa pada tahun 2013 surplus underwriting mengalami penurunan dari tahun sebelumnya. Hal ini dapat dipengaruhi oleh naik turunnya jumlah kontribusi, klaim, maupun investasi pada tahun tersebut. Surplus underwriting mengalami penurunan pada tahun 2013 walaupun jumlah kontribusi dan investasi mengalami kenaikan, dimana kontribusi dan investasi merupakan salah satu faktor penambah surplus underwriting. Hal ini bisa terjadi karena kontribusi yang ada dalam tabel diatas merupakan kontribusi bruto, sedangkan surplus underwriting dana tabarru' didapatkan setelah mengetahui jumlah kontribusi neto suatu perusahaan asuransi syariah. Setelah didapatkan hasil kontribusi neto maka akan dikurangi dengan klaim dan ditambah dengan hasil investasi dana tabarru', apabila masih terdapat sisa maka itu disebut sebagai surplus underwriting dana tabarru'. Dalam hal ini, kontribusi dan investasi adalah sebagai faktor penambah dana tabarru' dan klaim sebagai pengurang.

\section{RUMUSAN MASALAH}

Melalui latar belakang di atas maka rumusan masalah yang dapat dibuat adalah:

1. Apakah Kontribusi Neto berpengaruh terhadap surplus underwriting dana tabarru' pada asuransi jiwa syariah di Indonesia?

2. Apakah Beban Klaim berpengaruh terhadap surplus underwriting dana tabarru' pada asuransi jiwa syariah di Indonesia?

3. Apakah Hasil Investasi berpengaruh terhadap surplus underwriting dana tabarru' pada asuransi jiwa syariah di Indonesia?

4. Apakah Kontribusi Neto, Beban Klaim dan Hasil Investasi secara simultan berpengaruh terhadap surplus underwriting dana tabarru' pada asuransi jiwa syariah di Indonesia? 
Alifianingrum, et al/ Jurnal Ekonomi Syariah Teori dan Terapan Vol. 5 No. 2 Februari 2018: 144158; FAKTOR-FAKTOR YANG MEMPENGARUHI SURPLUS UNDERWRITING DANA TABARRU' PADA PERUSAHAAN ASURANSI JIWA SYARIAH

TUJUAN

1. Mengetahui pengaruh Kontribusi Neto terhadap surplus underwriting dana tabarru' pada asuransi jiwa syariah di Indonesia.

2. Mengetahui pengaruh Beban Klaim terhadap surplus underwriting dana tabarru' pada asuransi jiwa syariah di Indonesia.

3. Mengetahui pengaruh Hasil Investasi terhadap surplus underwriting dana tabarru' pada asuransi jiwa syariah di Indonesia.

4. Mengetahui pengaruh Kontribusi Neto, Beban Klaim dan Hasil Investasi terhadap surplus underwriting dana tabarru' pada asuransi jiwa syariah di Indonesia.

\section{LANDASAN TEORI}

\section{Asuransi Jiwa Syariah}

Menurut Undang-Undang Republik Indonesia Nomor 40 Tahun 2014 tentang Peransuransian, pengertian asuransi jiwa syariah adalah usaha pengelolaan resiko berdasarkan Prinsip Syariah guna saling menolong dan melindungi dengan memberikan pembayaran yang didasarkan pada meninggal atau hidupnya peserta, atau pembayaran lain kepada peserta atau pihak lain yang berhak pada waktu tertentu yang diatur dalam perjanjian, yang besarnya telah ditetapkan dan/atau didasarkan pada hasil pengelolaan dana.

\section{Konsep Dana Tabarru'}

Menurut Fatwa Dewan Syariah Nasional-Majelis Ulama Indonesia No. 81/DSN-MUI/III/2011 tentang Pengembalian
Dana Tabarru' bagi Peserta Asuransi yang Berhenti Sebelum Masa Perjanjian Berakhir, dana tabarru' adalah iuran/hibah sejumlah dana kepesertaan asuransi yang diberikan oleh peserta asuransi syariah individu kepada peserta secara kolektif sesuai dengan kesepakatan.

\section{Konsep Underwriting}

Underwriting yaitu proses penyelesaian dan pengelompokkan resiko yang akan ditanggung. Underwriting maksudnya adalah memaksimalkan laba melalui penerimaan distribusi risiko yang diperkirakan akan mendatangkan laba, tanpa adanya underwriting yang efisien, perusahaan asuransi tidak akan mampu bersaing (Darmawi, 2004: 31-32).

\section{Surplus (Defisit) Underwriting Dana Tabarru'}

Menurut Sula (2004: 180), surplus underwriting dana tabarru' diperoleh dari kumpulan dana peserta yang diinvestasikan (insurance fund), lalu dikurangi dengan biaya-biaya atau beban asuransi seperti reasuransi dan klaim (dana tabarru'). Kemudian surplus tersebut dibagi hasil antara peserta dan perusahaan sesuai dengan nisbah yang telah ditentukan. Bagian perusahaan inilah yang diambil sebagai biaya operasional sebelum menjadi profit perusahaan.

Menurut Ali dkk, (2002: 309), surplus dana tabarru' adalah hasil pengurangan dari dana tabarru' peserta dikurangi dengan total jumlah klaim yang terjadi (beban tabarru') apabila hasil dari pengurangan tersebut bernilai positif, maka perusahaan akan mengalami 
Alifianingrum, et al/ Jurnal Ekonomi Syariah Teori dan Terapan Vol. 5 No. 2 Februari 2018: 144158; FAKTOR-FAKTOR YANG MEMPENGARUHI SURPLUS UNDERWRITING DANA TABARRU' PADA PERUSAHAAN ASURANSI JIWA SYARIAH

surplus, dan apabila hasil dari

diharapkan akan memberikan pengurangan bernilai negatif, maka perusahaan akan mengalami defisit.

\section{Kontribusi Neto}

Menurut Peraturan Menteri

Kevangan Nomor 11/PMK.010/2011

tentang Kesehatan Kevangan Usaha

Asuransi dan Usaha Reasuransi dengan

Prinisp Syariah mendefinisikan kontribusi neto adalah selisih lebih kontribusi dari peserta asuransi yang dialokasikan untuk dana tabarru' ditambah kontribusi reasuransi diterima dengan kontribusi reasuransi keluar. Dalam laporan keuangan perusahaan asuransi syariah, kontribusi neto adalah kontribusi bruto dikurangi ujroh pengelola, reasuransi dan perubahan kontribusi yang belum menjadi hak.

\section{Beban Klaim}

Menurut fatwa Dewan Syariah Nasional Majelis Ulama Indonesia No.21/DSN-MUI/X/2001 tentang pedoman umum asuransi syariah, klaim adalah hak peserta yang merupakan kewajiban perusahaan asuransi untuk memenuhinya, klaim dibayarkan berdasarkan akad yang disepakati pada awal perjanjian. Klaim erat kaitannya dengan kerugian. Menurut Sula (2004: 259), kerugian dibagi menjadi tiga jenis, antara lain: (1) Kerugian seluruhnya (total loss), (2) Kerugian sebagian (partial loss), dan (3) Kerugian pihak ketiga.

\section{Hasil Investasi}

Investasi adalah penanaman sejumlah modal/aset baik berupa harta maupun dana pada sesuatu yang

keuntungan di masa yang akan datang. Sedangkan hasil investasi adalah penghasilan dari portofolio investasi aktiva perusahaan asuransi.

Menurut fatwa Dewan Syariah Nasional, Majelis Ulama Indonesia No.53/DSN-MUI/III/2006 tentang akad Tabarru' pada asuransi syariah bahwa hasil investasi dari dana tabarru' menjadi hak kolektif peserta dan dibukukan dalam akun tabarru'. Dari hasil investasi, perusahaan asuransi dapat memperoleh bagi hasil berdasarkan akad mudharabah atau akad mudharabah musytarakah, atau memperoleh ujrah (fee) berdasarkan akad wakalah bil ujrah.

\section{HIPOTESIS PENELITIAN}

Berdasarkan latar belakang, rumusan masalah, tujuan penelitian, landasan teori yang telah dikemukakan, maka hipotesis dalam penelitian adalah:

$\mathrm{Hl}$ : Kontribusi neto berpengaruh secara signifikan terhadap surplus underwriting dana tabarru' pada asuransi jiwa syariah di Indonesia.

H2: Beban Klaim berpengaruh secara signifikan terhadap surplus underwriting dana tabarru' pada asuransi jiwa syariah di Indonesia.

H3: Hasil Investasi berpengaruh secara signifikan terhadap surplus underwriting dana tabarru' pada asuransi jiwa syariah di Indonesia.

H4: Kontribusi Neto, Beban Klaim, dan Hasil Investasi bersama-sama berpengaruh secara signifikan 
Alifianingrum, et al/ Jurnal Ekonomi Syariah Teori dan Terapan Vol. 5 No. 2 Februari 2018: 144158; FAKTOR-FAKTOR YANG MEMPENGARUHI SURPLUS UNDERWRITING DANA TABARRU' PADA PERUSAHAAN ASURANSI JIWA SYARIAH

terhadap surplus underwriting

dana tabarru' pada asuransi jiwa

syariah di Indonesia.

\section{METODE PENELITIAN}

\section{Pendekatan Penelitian}

Pendekatan yang digunakan dalam penelitian ini adalah penelitian kuantitatif dengan metode analisis regresi data panel. Metode regresi data panel digunakan untuk mengetahui apakah ada pengaruh yang signifikan dari variabel independen yang jumlahnya lebih dari satu terhadap variabel dependen, data ini merupakan gabungan dari time series dan cross section.

\section{Definisi Operasional Variabel}

\section{Surplus (defisit) Underwriting Dana Tabarru'}

Surplus (defisit) underwriting dana tabarru' adalah hasil pengurangan dari dana tabarru' peserta dikurangi dengan total jumlah klaim yang terjadi (beban tabarru') apabila hasil dari pengurangan tersebut bernilai positif, maka perusahaan akan mengalami surplus, dan apabila hasil dari pengurangan bernilai negative, maka perusahaan akan mengalami defisit.

\section{Kontribusi Neto}

Kontribusi neto pada dasarnya merupakan bagian dari kontribusi bruto. Kontribusi bruto adalah sejumlah dana yang dibayarkan oleh peserta asuransi syariah yang terdiri dari dana tabungan dan dana tabarru' namun belum dikurangi biaya-biaya yang ada. Dalam laporan kevangan perusahaan asuransi syariah, kontribusi neto adalah kontribusi bruto dikurangi dengan ujroh pengelola, reasuransi, dan perubahan kontribusi yang belum menjadi hak.

\section{Beban Klaim}

Beban Klaim adalah pengeluaran pada perusahaan asuransi untuk memenuhi kewajiban membayar klaim pada periode berjalan. Klaim adalah hak peserta yang merupakan kewajiban bagi perusahaan asuransi untuk memenuhinya dan jumlah klaim yang dibayarkan oleh perusahaan kepada peserta yaitu berdasarkan akad yang disepakati pada awal perjanjian. Klaim diajukan oleh peserta asuransi ketika mengalami kerugian/musibah.

\section{Hasil Investasi}

Dalam perusahaan asuransi syariah, hasil investasi yang dimaksud adalah total pendapatan investasi yang telah ditanamkan kemudian dikurangi dengan beban pengelolaan portofolio investasi. Perusahaan asuransi syariah adalah sebagai pengelola dana peserta yang harus melakukan investasi terhadap dana yang terkumpul dan investasi harus dilakukan sesuai dengan prinsip syariah. Dari hasil investasi yang dilakukan, maka perusahaan asuransi juga akan memperoleh bagi hasil berdasarkan akad mudharabah.

\section{Jenis dan Sumber Data}

Data yang digunakan dalam penelitian ini adalah data sekunder 
Alifianingrum, et al/ Jurnal Ekonomi Syariah Teori dan Terapan Vol. 5 No. 2 Februari 2018: 144158; FAKTOR-FAKTOR YANG MEMPENGARUHI SURPLUS UNDERWRITING DANA TABARRU' PADA PERUSAHAAN ASURANSI JIWA SYARIAH

berupa laporan keuangan tahunan metode ini setringkali disebut perusahaan asuransi jiwa syariah di Indonesia tahun 2011 sampai 2015.

\section{Populasi dan Sampel}

Populasi dalam penelitian ini adalah seluruh Asuransi Jiwa Syariah di Indonesia yang terdaftar dalam OJK. Pengambilan sampel dalam penelitian ini dilakukan dengan purposive sampling, dengan kriteria perusahaan asuransi jiwa yang menerbitkan laporan kevangan pada tahun penelitian 2011-2015.

\section{Teknik Analisis Data}

\section{Estimasi Regresi Data Panel}

Menurut Grenee (1991:481) dalam mengestimasi data panel terdapat tiga pendekatan yang biasa dilakukan, yaitu model Common Effect Model (CEM), Fixed Effect Model (FEM), dan Random Effect Model (REM).

1. Common Effect Model (CEM)

Teknik paling sederhana untuk mengestimasi data panel adalah dengan mengkombinasikan data time series dan cross section. Dengan hanya menggabungkan data tersebut tanpa melihat perbedaan anytar waktu dan individu, maka dapat menggunakan metode OLS untuk mengestimasi model data panel (Widarjono, 2013:355).

2. Fixed Effect Model (FEM)

Teknik model fixed effect adalah teknik mengestimasi data panel dengan menggunakan variabel dummy untuk menangkap adanya perbedaan intersep, sehingga

dengan Least Square Dummy Variable (LSDV). Model ini didasarkan adanya perbedaan intersep antara subjek penelitian namun intersepnya sama antar waktu (time invariant). Disamping itu, model ini juga mengasumsikan bahwa koefisien regresi (slope) adalah tetap untuk antar subjek penelitian dan antar waktu (Widarjono, 2013:356).

3. Random Effect Model (REM)

Model ini mengestimasi data panel dimana variabel gangguan mungkin saling berhubungan antar waktu dan antar individu dan diasumsikan setiap subjek penelitian memiliki perbedaan intersep (Widarjono, 2013:359). Menurut Gujarati dan Dawn (2013:250) model ini memperhitungkan error dari cross section dan time series.

\section{Pemilihan Model Regresi Data Panel}

Untuk memilih model mana yang paling tepat digunakan untuk pengolahan data panel, maka terdapat beberapa pengujian yang dapat dilakukan yaitu uji $F$ statistik dan uji Hausman.

1. Chow Test

Pengujian untuk memilih apakah model yang digunakan menggunakan common effect atau fixed effect ( Widarjono, 2013:362). Dalam pengujian ini dilakukan hipotesis sebagai berikut:

$\mathrm{H}_{0}=$ Common Effect Model 
Alifianingrum, et al/ Jurnal Ekonomi Syariah Teori dan Terapan Vol. 5 No. 2 Februari 2018: 144158; FAKTOR-FAKTOR YANG MEMPENGARUHI SURPLUS UNDERWRITING DANA TABARRU' PADA PERUSAHAAN ASURANSI JIWA SYARIAH

$\mathrm{Ha}=$ Fixed Effect Model

2. Hausman Test

Pengujian statistik sebagai dasar pertimbangan dalam memilih apakah menggunakan model fixed effect atau model random effect. Pengujian ini dilakukan dengan hipotesis sebagai berikut :

$\mathrm{H}_{0}=$ Random Effect Model

$\mathrm{H}_{\mathrm{a}}=$ Fixed Effect Model

Dasar penolakan terhadap $\mathrm{H}_{0}$ adalah dengan mengikuti distribusi statistik Chi Square dengan degree of freedom sebanyak $k$ dimana $k$ adalah jumlah variabel independen. Jika nilai statistik Hausman (Chi Square Statistics) > nilai kritis Chi Square maka Ho ditolak atau model yang tepat adalah fixed effect. Sebaliknya, jika nilai statistik Hausman (Chi Square Statistics) < nilai kritis Chi Square maka $\mathrm{H}_{0}$ diterima atau model yang tepat adalah random effect (Widarjono, 2013:365).

\section{Uji Hipotesis}

\section{Uji Parsial (Uji t)}

Uji † merupakan pengujian terhadap variabel-variabel bebas/independen secara parsial (individu) yang ditunjukkan untuk melihat signifikan dan pengaruh terhadap variabel dependen, dengan asumsi variabel independennya dianggap konstan.

\section{Uji Simultan (Uji F)}

Uji F digunakan untuk melihat apakah ada pengaruh variabel independen secara bersama-sama terhadap variabel dependen. Uji $F$ bisa dijelaskan dengan menggunakan varian (analysis of variance $=$ ANOVA).

\section{Analisis Koefisien Determinasi $\left(\mathbf{R}^{2}\right)$}

Koefisien determinasi

dimaksudkan untuk mengetahui tingkat ketepatan paling baik dalam menganalisis regresi, dimana hal yang ditunjukkan oleh besarnya koefisien determinasi ( $\left.\mathrm{R}^{2}\right)$ antara nol (0), dan 1. Koefisien determinasi dapat dicari dengan rumus :

$R^{2}=E S S=1$, nilai $R^{2}$ besarnya antara

$0-1\left(0 \leq R^{2} \leq 1\right)$

Koefisien determinasi $\left(\mathrm{R}^{2}\right)$ nol, berarti variabel independen sama sekali tidak berpengaruh terhadap variabel dependen. Apabila koefisien determinasi $\left(\mathrm{R}^{2}\right)$ mendekati satu, maka dapat dikatakan bahwa variabel independen berpengaruh terhadap variabel dependen.

\section{HASIL DAN PEMBAHASAN}

\section{Statistik Deskriptif}

Tabel 4.2

Statistik Deskriptif Surplus Underwriting, Kontribusi Neto, Beban Klaim, dan Hasil Investasi Tahun 2011-2015

\begin{tabular}{|c|c|c|}
\hline \multirow{4}{*}{ Surplus Underwriting } & Mean & 19358.44 \\
\hline & Min & -5576.000 \\
\hline & Max & 210862.0 \\
\hline & $S D$ & 39019.15 \\
\hline \multirow{4}{*}{ Kontribusi Neto } & Mean & 42869.49 \\
\hline & Min & 230.0000 \\
\hline & Max & 433978.0 \\
\hline & $S D$ & 81168.37 \\
\hline \multirow{4}{*}{ Beban Klaim } & Mean & 28987.07 \\
\hline & Min & -3129.000 \\
\hline & Max & 2666010.0 \\
\hline & $S D$ & 52739.56 \\
\hline \multirow{4}{*}{ Hasil Investasi } & Mean & 5524.686 \\
\hline & Min & -2086.000 \\
\hline & $\operatorname{Max}$ & 64203.00 \\
\hline & $S D$ & 11005.73 \\
\hline
\end{tabular}


Alifianingrum, et al/ Jurnal Ekonomi Syariah Teori dan Terapan Vol. 5 No. 2 Februari 2018: 144158; FAKTOR-FAKTOR YANG MEMPENGARUHI SURPLUS UNDERWRITING DANA TABARRU' PADA PERUSAHAAN ASURANSI JIWA SYARIAH Pemilihan Model Regresi Data Panel

Dalam penelitian ini, pemilihan model regresi data panel menggunakan uji Haussman, yaitu pengujian statistik untuk menentukan estimasi model Fixed Effect Model (FEM) atau Random Effect Model (REM). Hipotesis uji Haussman adalah:

$\mathrm{H}_{0} \quad=$ Permodelan Surplus Underwriting adalah Random Effect Model

$\mathrm{H}_{\mathrm{a}} \quad=$ Permodelan Surplus Underwriting adalah Fixed Effect Model

Tabel 4.6 dibawah ini menunjukkan hasil pengujian uji Hausman untuk data penelitian ini, yaitu sebagai berikut:

\section{Tabel 4.6}

Hasil Uji Model Menggunakan Haussman Test

Correlated Random Effects - Hausman Test

Equation: Untitled

Test cross-section random effects

\begin{tabular}{lrr}
\hline \hline & Chi-Sq. & Chi-Sq. \\
Test Summary & Statistic & d.f. Prob. \\
\hline \hline
\end{tabular}

Cross-section random $2.771678 \quad 30.4282$

Pada perhitungan statistik yang telah dilakukan diatas, dapat dilihat bahwa nilai probabilitas pada test cross section random effect memperlihatkan angka bernilai 0,4282 yang berarti tidak signifikan dengan tingkat signifikansi $95 \%$ $(a=5 \%)$ dan menggunakan distribusi ChiSquare (Gujarati,2013).

Sehingga bisa diambil keputusan dalam penelitian ini pada pengujian Hausmann test yaitu bahwa yang diterima adalah Ho ( $p$-value $>0,05)$. Dengan demikian model pilihan yang digunakan pada penelitian ini yaitu REM.

Tabel 4.7

Hasil Regresi Metode Random Effect Model (REM)

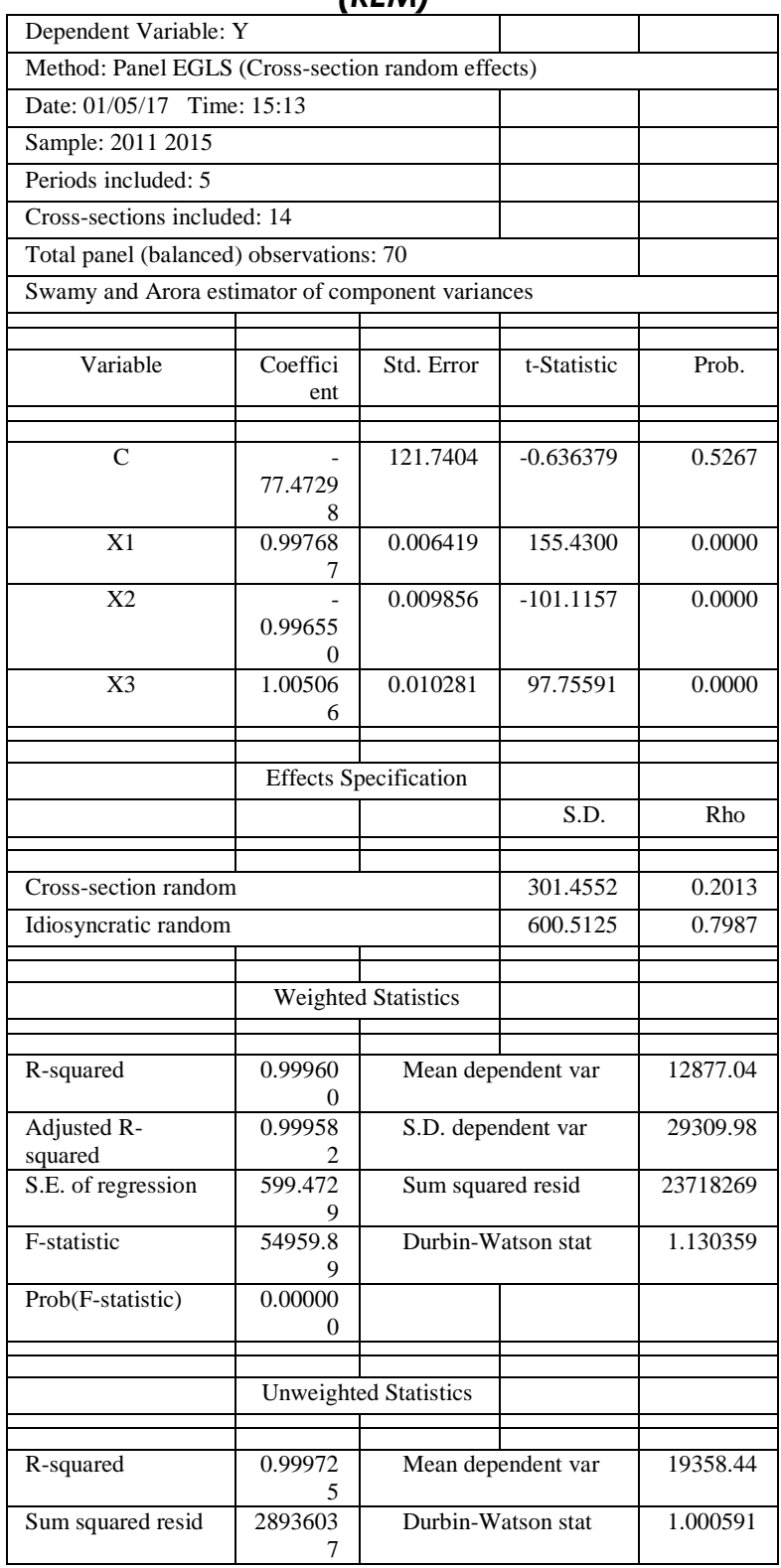

Hasil dari perhitungan Random Effect Model (REM) diatas menggunakan Eviews 8.0. Dari hasil tersebut dapat diketahui bahwa nilai R-square sebesar 0,999600. Artinya, bahwa variabel independen dapat menjelaskan variabilitas dependen (surplus underwriting) sebesar 99,96\%, sedangkan sisanya dijelaskan oleh variabel lain yang tidak dimasukkan dalam penelitian ini. 
Alifianingrum, et al/ Jurnal Ekonomi Syariah Teori dan Terapan Vol. 5 No. 2 Februari 2018: 144158; FAKTOR-FAKTOR YANG MEMPENGARUHI SURPLUS UNDERWRITING DANA TABARRU' PADA PERUSAHAAN ASURANSI JIWA SYARIAH

Uji Hipotesis

\section{Uji Simultan (F-test)}

Uji $F$ digunakan untuk menguji pengaruh secara simultan variabel independen terhadap variabel dependen. Terdapat dua hipotesis penelitian dalam uji $F$ ini yaitu sebagai berikut:

$\mathrm{H}_{0}=$ Variabel kontribusi neto, beban klaim, dan hasil investasi secara simultan berpengaruh tidak signifikan terhadap surplus underwriting.

$\mathrm{H}_{1}=$ Variabel kontribusi neto, beban klaim, dan hasil investasi secara simultan berpengaruh signifikan terhadap surplus underwriting.

Dalam menentukan hipotesis diterima atau ditolak, terdapat ketentuan yang harus dipenuhi. Ho diterima apabila nilai probability $>0,05$, sebaliknya $\mathrm{H}_{0}$ ditolak apabila nilai probability $<0,05$. Pada Tabel 4.8 menjelaskan hasil uji $F$ menggunakan Eviews 8.0 sebagai berikut:

Tabel 4.8 Hasil Uji Simultan (F-test)

\begin{tabular}{|c|c|}
\hline F-Hitung & 54959,89 \\
\hline Prob (F-statistic) & 0,000000 \\
\hline
\end{tabular}

Berdasarkan pada Tabel 4.8 diatas, dapat dilihat bahwa nilai F-hitung adalah sebesar 54959,89 dan hasil nilai probability F-statistic adalah 0,000000 kurang dari a $(0,05)$ artinya $\mathrm{H}_{0}$ ditolak dan $\mathrm{H}_{1}$ diterima, dapat disimpulkan bahwa variabel kontribusi neto, beban klaim, dan hasil investasi secara simultan berpengaruh signifikan terhadap surplus (defisit) underwriting dana tabarru' pada perusahaan asuransi jiwa syariah di Indonesia tahun 2011-2015.

Uji Parsial (t-test)

Uji $\dagger$ digunakan untuk menguji dan membuktikan apakah variabel independen secara individu mempengaruhi variabel dependennya (Widarjono, 2010:25). Hipotesis statistik dari uji-† adalah sebagai berikut:

$\mathrm{H}_{0}=$ Variabel independen berpengaruh tidak signifikan terhadap variabel dependen secara parsial.

$\mathrm{H}_{1} \quad=\quad$ Variabel independen berpengaruh signifikan terhadap variabel dependen secara parsial.

Kriteria dalam penerimaan $\mathrm{H}_{0}$ dan $\mathrm{H}_{1}$ adalah dengan melihat nilai probability. Jika nilai signifikansi lebih kecil dari 0,05 maka $\mathrm{H}_{0}$ ditolak dan $\mathrm{H}_{1}$ diterima. Sebaliknya, jika nilai probability lebih besar dari 0,05 maka $\mathrm{H}_{0}$ diterima dan $\mathrm{H}_{1}$ ditolak.

Tabel 4.9

Hasil Estimasi Uji $\uparrow$

\begin{tabular}{|c|c|c|c|}
\hline Variabel & Probability & $\begin{array}{c}\text { Loss } \\
(\alpha)\end{array}$ & Keterangan \\
\hline KNT & 0,0000 & & $\begin{array}{c}\text { Nilai prob }<(\alpha): \mathrm{H}_{0} \\
\text { ditolak }\end{array}$ \\
\cline { 1 - 1 } KLM & 0,0000 & \multirow{2}{*}{0,05} & $\begin{array}{c}\text { Nilai prob }<(\alpha): \mathrm{H}_{0} \\
\text { ditolak }\end{array}$ \\
& & & $\begin{array}{c}\text { Nilai prob }<(\alpha): \mathrm{H}_{0} \\
\text { ditolak }\end{array}$ \\
\hline
\end{tabular}

Berdasarkan pengujian pada Tabel 4.9 diatas, dapat diketahui bahwa variabel kontribusi neto, beban klaim, dan hasil investasi secara parsial berpengaruuh signifikan terhadap surplus underwriting dana tabarru' pada perusahaan asuransi jiwa syariah di Indonesia. 
Alifianingrum, et al/ Jurnal Ekonomi Syariah Teori dan Terapan Vol. 5 No. 2 Februari 2018: 144158; FAKTOR-FAKTOR YANG MEMPENGARUHI SURPLUS UNDERWRITING DANA TABARRU' PADA PERUSAHAAN ASURANSI JIWA SYARIAH

Analisis Koefisien Determinasi $\left(\mathbf{R}^{2}\right)$

Koefisien determinasi bertujuan untuk mengetahui seberapa besar variabel independen dapat menjelaskan variabel dependen atau bisa disebut untuk mengetahui keakuratan hubungan variabel dependen dan independen.

Tabel 4.10

Hasil Estimasi Uji R²

\begin{tabular}{|c|c|c|}
\hline $\mathbf{R}^{\mathbf{2}}$ & $\begin{array}{c}\text { Adjusted } \\
\mathbf{R}^{\mathbf{2}}\end{array}$ & $\begin{array}{c}\text { Interpretasi } \\
\text { Hasil }\end{array}$ \\
\hline 0,999818 & 0,999763 & $\begin{array}{c}\text { Nilai } \mathbf{R}^{2} \text { tersebut } \\
\text { mengindikasikan } \\
\text { bahwa variabel } \\
\text { independen } \\
\text { secara simultan } \\
\text { dapat }\end{array}$ \\
& & $\begin{array}{c}\text { menjelaskan } \\
\text { variabel } \\
\text { dependen } \\
\end{array}$ \\
& & sebesar 99,9\% \\
\hline
\end{tabular}

Pada Tabel 4.10 koefisien determinasi sebesar 0,999818 atau 99,98\%. Angka tersebut menunjukkan bahwa variabel surplus underwriting dapat dijelaskan oleh variabel kontribusi neto, beban klaim, dan hasil investasi sebesar 99,98\%. Besar kontribusi neto, beban klaim, dan hasil investasi terhadap surplus underwriting asuransi jiwa syariah di Indonesia tahun 2011-2015 yaitu sebesar $99,98 \%$ dan sisanya $0,02 \%$ dipengaruhi oleh faktorfaktor lain yang tidak dimasukkan dalam penelitian.

\section{SIMPULAN}

Berdasarkan hasil analisis dan interpretasi data yang dilakukan maka dapat diambil kesimpulan sebagai berikut:

1. Kontribusi Neto memberikan pengaruh positif dan signifikan terhadap surplus underwriting dana tabarru' dengan nilai a sebesar 5\% atau 0,05 .

2. Beban Klaim memberikan pengaruh negatif dan signifikan terhadap surplus underwriting dana tabarru' dengan nilai a sebesar $5 \%$ atau 0,05.

3. Hasil Investasi memberikan pengaruh positif dan signifikan terhadap surplus underwriting dana tabarru' yang ditunjukkan dengan nilai nilai a sebesar $5 \%$ atau 0,05 .

4. Variabel Kontribusi Neto, Beban Klaim, dan Hasil Investasi berpengaruh signifikan secara simultan terhadap Surplus underwriting dana tabarru' dengan nilai a sebesar $5 \%$ atau 0,05 .

\section{DAFTAR PUSTAKA}

Ali, A. Hasyim, dkk. 2002. Kamus Asuransi. Jakarta: Bumi Aksara.

Ali, Hasan. 2004. Asuransi dalam Perspektif Hukum Islam. Jakarta: Prenada Media.

Ali, Zainuddin. 2008. Hukum Asuransi Syariah. Jakarta: Sinar Grafika.

Amrin, Abdullah. 2006. Asuransi Syariah (Keberadaan dan Kelebihannya di Tengah Asuransi Konvensional). Jakarta: PT Elex Media Komputindo.

Damayanti, Febrinda Eka. 2016. Pengaruh Kontribusi Peserta, Klaim, dan Hasil Investasi terhadap Surplus Underwriting Asuransi Umum Syariah. Skripsi tidak diterbitkan. Universitas Airlangga.

Danim, Sudarwan. 1997. Metode Penelitian untuk IImu-IImu Perilaku 
Alifianingrum, et al/ Jurnal Ekonomi Syariah Teori dan Terapan Vol. 5 No. 2 Februari 2018: 144158; FAKTOR-FAKTOR YANG MEMPENGARUHI SURPLUS UNDERWRITING DANA TABARRU' PADA PERUSAHAAN ASURANSI JIWA SYARIAH

Acuan Dasar Bagi Mahasiswa

Program Sarjana dan Peneliti

Pemula. Cetakan Pertama.

Jakarta: Bumi Aksara.

Darmawi, Herman. 2004. Manajemen Asuransi. Edisi Pertama. Cetakan Ketiga. Jakarta: PT Bumi Aksara.

Dewi, Gemala. 2004. Aspek-aspek Hukum dalam Perbankan dan Peransuransian Syariah di Indonesia. Prenada Media. Jakarta.

Fatwa Dewan Syariah Nasional No: 21/DSN-MUI/X/2001 Tentang Pedoman Umum Asuransi Syariah.

Fatwa Dewan Syariah Nasional No: 53/DSN-MUI/III/2006 Tentang Akad Tabarru' pada Asuransi Syariah.

Fatwa Dewan Syariah Nasional No: 81/DSN-MUI/III/2011 Tentang Pengembalian Dana Tabarru' Bagi Peserta Asuransi yang Berhenti Sebelum Masa Perjanjian Berakhir.

Fikri, M. Agung Ali. 2009. Pengaruh Premi, Klaim, Hasil Investasi dan Underwriting Terhadap Laba Asuransi Jiwa (Studi Kasus PT Asuransi Syariah Mubarakah). Skripsi tidak diterbitkan. Institut Pertanian Bogor.

Gujarati, Damodar N dan Dawn C. Porter. 2013. Dasar-Dasar Ekonometrika. Edisi 5 Buku 2. Jakarta: Salemba Empat. lqbal, Muhaimin. 2005. Asuransi Umum Syariah dalam Praktik. Jakarta: Gema Insani Press.

Karwati, Euis Lia. 2011. Metode Alokasi Surplus Underwriting Dana tabarru' pada Asuransi Kerugian Syariah. Skripsi tidak diterbitkan. UIN Syarif Hidayatullah Jakarta.

Kirmizi \& Susi Surya Agus. 2011. Pengaruh Pertumbuhan Modal dan Aset terhadap Rasio Risk Based Capital (RBC), Pertumbuhan Premi Neto dan Profitabilitas Perusahaan Asuransi Umum di Indonesia. Pekbis Jurnal, Volume 3 (Nomor 1): 391405.

Nurcahya, Suci Ekawati. 2012. Analisis Pengaruh Kontribusi Bruto, Reasuransi, Pembayaran Klaim dan Pendapatan Investasi Netto terhadap Surplus (Defisit) Underwriting Dana Tabarru' pada Perusahaan Asuransi Jiwa Syariah di Indonesia. Skripsi tidak diterbitkan. Universitas Airlangga.

Otoritas Jasa Keuangan (OJK). 2016. Daftar Perusahaan Asuransi Umum, Jiwa dan Reasuransi dengan Prinsip Syariah 2016. (Sumber: http://www.ojk.go.id/id/DaftarPerusahaan-Asuransi-Umum-Jiwa,dan-Reasuransi-dengan-PrinsipSyariah, diakses pada tanggal 26 September 2016)

Otoritas Jasa Keuangan. 2016. Statistik Peransuransian 2012. (Sumber: www.ojk.go.id/id/kanal/iknb/datadan- 
Alifianingrum, et al/ Jurnal Ekonomi Syariah Teori dan Terapan Vol. 5 No. 2 Februari 2018: 144158; FAKTOR-FAKTOR YANG MEMPENGARUHI SURPLUS UNDERWRITING DANA TABARRU' PADA PERUSAHAAN ASURANSI JIWA SYARIAH

statistik/asuransi/Pages/statistik-

peransuransian-2012.aspx, diakses

pada tanggal 14 September 2016)

Otoritas Jasa Keuangan. 2016. Statistik

Peransuransian 2013. (Sumber:

www.ojk.go.id/id/kanal/iknb/data-

dan-

statistik/asuransi/Pages/statistik-

peransuransian-2013.aspx, diakses

pada tanggal 14 September 2016)

Otoritas Jasa Keuangan. 2016. Statistik

Peransuransian 2014. (Sumber:

www.ojk.go.id/id/kanal/iknb/data-

dan-

statistik/asuransi/Pages/statistik-

peransuransian-2014.aspx, diakses

pada tanggal 14 September 2016)

Pangestika, Styfanda. 2015. Analisis

Estimasi Model Regresi Data Panel dengan Pendekatan Common Effect Model (CEM), Fixed Effect Model (FEM), dan Random Effect Model (REM). Skripsi tidak diterbitkan. Universitas Negeri Semarang.

Republik Indonesia. 2011. Peraturan Menteri Kevangan Nomor 11/PMK.010/2011 Tentang Kesehatan Kevangan Usaha Asuransi dan Usaha Reasuransi dengan Prinsip Syariah. Kementrian Keuangan. Jakarta.

Republik Indonesia. 2014. Undang-Undang Republik Indonesia Nomor 40 Tahun $2014 \quad$ Tentang Peransuransian. Sekretariat Negara. Jakarta.
Republik Indonesia. 2010. Peraturan Menteri Keuangan Nomor 18/PMK.010/2010 Tentang Penerapan Prinsip Dasar Penyelenggaraan Usaha Asuransi dan Usaha Reasuransi dengan Prinsip Syariah. Kementrian Keuangan. Jakarta.

Republik Indonesia. 2003. Keputusan Menteri Keuangan Republik Indonesia Nomor 424/KMK.06/2003 Tentang Kesehatan Keuangan Perusahaan Asuransi dan Perusahaan Reasuransi. Kementrian Keuangan. Jakarta.

Republik Indonesia. 2000. Keputusan Direktur Jenderal Lembaga Keuangan Nomor Kep. 4499/LK/2000 Tentang Jenis, Penilaian, dan Pembatasan Investasi Perusahaan Asuransi dan Reasuransi dengan Sistem Syariah. Dirjen Keuangan. Jakarta.

Satata, Elsha Dwi Angganis. 2015. Pengaruh Premi dan Hasil Investasi serta Surplus Underwriting Dana Tabarru' terhadap Laba Asuransi PT. Asuransi Jasindo Takaful. Skripsi tidak diterbitkan. Universitas Airlangga.

Salim, A. Abbas. 1995. Dasar-Dasar Asuransi. Jakarta: PT Raja Grafindo Persada

Sugiyono. 2012. Metode Penelitian Kuantitatif, Kualitatif dan R\&D. Bandung: Alfabeta. 
--------. 2013. Metode Penelitian Bisnis (Pendekatan Kuantitatif, Kualitatif dan R\&D). Bandung: Alfabeta.

Sula, Muhammad Syakir. 2004. Asuransi

Syariah (Life and General).

Cetakan 1. Jakarta: Gema Insani Press.

Suma, Muhammad Amin. 2006. Asuransi Syariah dan Asuransi Konvensional Teori, Sistem dan Pemasaran. Tangerang: Kolom Publishing.

Supriyanto, Al Torik. 2015. Pengaruh Pendapatan Premi dan Hasil Investasi terhadap Cadangan Dana Tabarru' Pada Perusahaan Asuransi Syariah di Indonesia. Skripsi tidak diterbitkan. Universitas Negeri Yogyakarta.

Widarjono, Agus. 2010. Analisis Statistika Multivariat Terapan. Yogyakarta: UPP STIM YKPN 2013. Ekonometrika (Pengantar dan Aplikasinya). Edisi Keempat. Yogyakarta: UPP STIM YKPN.

Wirdyaningsih, dkk. 2005. Bank dan Asuransi Islam di Indonesia. Jakarta: Kencana

Prenada Media. 